\title{
Język i obraz wobec koronawirusa Przyczynek do rozważań nad komunikacją medialną $w$ czasach pandemii
}

Language, Image, and Coronavirus:

A Contribution to the Discussion on Media Communication During a Pandemic

\begin{abstract}
This article is a contribution to the discussion on communication during the coronavirus pandemic. The material for this media- and linguistic-oriented analysis consists of the linguistic and visual layers of media terts dedicated to the pandemic and published between March until September 2020 in Polish analog and digital media (among others: "Polityka," "Newsweek," "Tygodnik Powszechny," and social media). The purpose of this article is to answer the question of verbal and visual narrations about the coronavirus are built. The article presents and describes elements of so-called coronalanguage: neologisms created for communication purposes during the pandemic. This media-linguistic analysis also concerns selected weekly magazine covers, the verbal and visual layers of which address the topic of the pandemic, including the restrictions, ansieties and threats that have accompanied it.
\end{abstract}

Key words: media communication, communication during the pandemic

\begin{abstract}
Abstrakt: Artykuł stanowi głos $w$ dyskusji nad komunikacją w czasach pandemii koronawirusa. Przedmiotem analizy mediolingwistycznej autorka czyni warstwę językową i obrazową tekstów medialnych poświęconych pandemii i opublikowanych w okresie od marca do września 2020 roku w polskich mediach analogowych i cyfrowych (m.in. „Polityka”, „Newsweek”, „Tygodnik Powszechny” oraz media społecznościowe). Celem podjętym w opracowaniu jest udzielenie odpowiedzi na pytanie o sposób budowania werbalnej i wizualnej narracji wokół koronawirusa. W artykule zaprezentowane i opisane zostaną elementy tzw. koronajęzyka, tj. neologizmy powstałe na użytek komunikacji w czasach pandemii. Analizie mediolingwistycznej poddane będą także okładki wybranych tygodników, na których - w warstwie werbalnej i wizualnej - podjęto temat pandemii, $w$ tym ograniczeń, obaw i zagrożeń z nią związanych.
\end{abstract}

Słowa kluczowe: komunikacja medialna, komunikacja w czasach pandemii

\section{Wprowadzenie}

Rok 2020 w polskich mediach zdominowały dwa tematy, które - chociaż pozornie dalekie - ściśle się z sobą wiązały i wzajemnie przenikały. Pierwszym z nich było pojawienie się tzw. koronawirusa i wywołanej nim pandemii, drugim zaś - wybory prezydenckie i poprzedzająca je kampania wyborcza, która rozpoczęła się 5 lutego 2020 roku i w związku z wystąpieniem zagrożenia epidemicznego trwała aż pół roku (II tura wybo- 
rów prezydenckich odbyła się dopiero 12 lipca 2020 roku). W Polsce pierwszy przypadek koronawirusa odnotowano 4 marca 2020 roku, jednak już kilka tygodni wcześniej zaczęto bacznie obserwować sytuację na świecie, a dyskurs medialny wypełniły różne scenariusze rozwoju epidemii i jej wpływu na życie społeczne, polityczne, gospodarcze i kulturalne Polaków, w tym także na dynamikę kampanii wyborczej. W kolejnych miesiącach dało się zauważyć, jak silnie pandemia koronawirusa rzutowała także na język używany zarówno przez dziennikarzy, jak i polityków czy zwykłych użytkowników mediów1. Bezpośrednie odniesienia do koronawirusa pojawiały się nie tylko $w$ tekstach publicystycznych, ale także w wystąpieniach polityków zaangażowanych w kampanię wyborczą. W mediach można było znaleźć wiele dowodów na to, że pojawienie się koronawirusa przyczyniło się $w$ języku polskim do: 1) powstania nowych słów, 2) upowszechnienia pojęć uważanych dotąd za wysoce specjalistyczne oraz 3) nadania nowego znaczenia słowom już istniejącym. Podobne zjawiska dało się zaobserwować w sferze wizualnej, gdyż motyw koronawirusa był intensywnie wykorzystywany $w$ materiałach graficznych publikowanych $w$ mediach analogowych i cyfrowych.

Celem podjętym $w$ artykule jest analiza polskich tekstów medialnych, powstałych od marca do września 2020 roku i dotyczących problematyki związanej z pandemią koronawirusa. Przedmiotem analizy są współtworzące dyskurs pandemiczny elementy językowe i obrazowe zróżnicowanych semiotycznie tekstów medialnych pochodzących od nadawców instytucjonalnych i prywatnych. Spośród 86 numerów „Polityki”, „Newsweeka” i „Tygodnika Powszechnego", które ukazały się od marca od września 2020 roku, do dalszej analizy mediolingwistycznej zakwalifikowano 21 wydań, których głównym tematem anonsowanym na okładkach jest pandemia koronawirusa. Analiza tychże okładek ma posłużyć znalezieniu odpowiedzi na pytanie o to, po jakie rozwiązania multimodalne odwołujące się do teorii designu tekstu (por. Bucher 2007; Lugınbühl 2015) sięgają nadawcy komunikatu, by wzmocnić przekaz dotyczący pandemii i przykuć uwagę odbiorców. Z kolei badanie warstwy werbalnej tychże okładek oraz anonsowanych na nich artykułów poświęconych koronawirusowi ma prowadzić do wskazania pojęć z zakresu tzw. koronajęzyka, czyli takich, które mają związek z pandemią i są w polszczyźnie nowe lub też nabrały nowego znaczenia².

\section{Koronawirus - pochodzenie, znaczenie}

Jak podaje Wielki słownik języka polskiego pod redakcją Piotra Żmigrodzkiego koronawirus to „wirus mający otoczkę białkową z wypustkami przypominającymi koronę, wywołujący choroby układu oddechowego u ludzi i różne choroby u zwierząt”3. Rzeczownik ten

1 Silny wpływ pandemii koronawirusa na język odnotowano w wielu krajach, $w$ tym $w$ obszarze niemieckojęzycznym, czego dowodem mogą być np. badania prowadzone przez naukowców skupionych wokół Instytutu Języka Niemieckiego w Mannheim (por. KlosA-KücKenhaus, 2020; Müller-SPITZER, Tittula, Gutier, Taborek, 2020; Wolfer, Koplenig, Michaelis, 2020).

2 Jako uzupełnienie bazy językowej posłużyły zasoby Twittera (wyszukiwane hasła: koronawirus, korona).

3 Por.: [online: https://www.wsjp.pl/inder.php?id_hasla=99350\&ind=0\&w_szukaj=koronawirus\#; data dostępu: 1.10.2020]. 
wywodzi się od ang. coronavirus, od którego odróżnia go forma graficzna $(c \rightarrow k, v \rightarrow w)$, i stanowi złożenie powstałe na bazie dwóch rzeczowników, tj. korona i wirus. Słowo korona wywodzi się z łac. corōna 'korona, wieniec' oraz gr. korốnré 'zakrzywiony przedmiot; pierścień’ i na gruncie polskim odnoszone jest zazwyczaj do obręczy wykonanej przeważnie ze złota, zdobionej drogimi kamieniami, noszonej na głowie przez władców jako symbol władzy (= korona królewska) ${ }^{4}$. To może tłumaczyć, dlaczego na gruncie polskim bardzo szybko zaczęto budować skojarzenia wirusa z tak rozumianą koroną. Jednak jak podkreśla Marek Łaziński, polski rzeczownik koronawirus powstał wprawdzie wskutek zapożyczenia angielskiego słowa coronavirus, ale ono wywodzi się od greckiej i łacińskiej corony, która pierwotnie nie miała nic wspólnego z nakryciem głowy, z jakim dzisiaj utożsamia się koronę, i odnosiła się właśnie do wieńca lub wręcz pewnej poświaty wokół głowy:

[...] korona królewska to po angielsku „crown”, po niemiecku „Krone”, nie „corona”. Język polski to jeden z niewielu języków, w których wirus wywołuje skojarzenia z królewską koroną i można stworzyć metaforę, jakoby koronawirus nad nami panował.

ŁAZIŃSKI, 2020

O tym, że koronawirus to zapożyczenie, świadczyć może fakt, że gdyby rzeczownik ten powstał bezpośrednio na gruncie języka polskiego, prawdopodobnie byłby wyposażony w morfem łączący - o- i brzmiałby koronowirus. Tymczasem WSJP podaje tę formę wprawdzie jako możliwą, ale jednak rzadziej stosowaną. Z kolei Katarzyna Kłosińska wariant koronowirus uważa za błędny, argumentując, że

poprawna jest nazwa koronawirus - wywodzi się ona od łacińskiego słowa corona (pol. korona), dlatego występuje w niej [a], nie [o]. Błędna forma koronowirus (z [o]) powstała w wyniku tzw. asymilacji (upodobnienia) głosek - po dwóch sylabach zawierających [o] łatwiej wymówić [o] niż [a] ${ }^{5}$.

KŁOSIŃSKA, 2020

Kluczowy dla tworzenia neologizmów pandemicznych wydaje się człon korona-. Wśród dziewiętnastu znaczeń rzeczownika korona w WSJP odnotowuje się, że współcześnie słowo to traktowane jest potocznie jako synonim epidemii i opisuje chorobę COVID-19 (wywoływaną przez jedną z odmian koronawirusa), która w 2020 roku spowodowała wybuch pandemii ${ }^{6}$. Oznacza to, że na przestrzeni ostatnich miesięcy rzeczownik korona otrzymał nowe znaczenie i może być używany do opisania czasu panowania koronawirusa. Agnieszka CiERPICH-Koziet dostrzega $w$ słowie korona neosemantyzm występujący $w$ dwóch znaczeniach: 1) 'nowy wirus, koronawirus', 2) 'czasy koronawirusa, okres pandemii' i podkreśla,

\footnotetext{
${ }^{4}$ [online: https://www.wsjp.pl/inder.php?id_hasla=2160\&id_znaczenia $=4831779 \&$ I=13\&ind=0; data dostępu: 1.10.2020].

${ }^{5}$ [online: https://sjp.pwn.pl/poradnia/haslo/Koronawirus;20058.html; data dostępu: 1.10.2020].

${ }^{6}$ [online: https://www.wsjp.pl/inder.php?id_hasla=2160\&id_znaczenia=5241819\&l=13\&ind=0; data dostępu: 1.10.2020].
} 
że „w znaczeniu drugim mamy do czynienia z uniwerbalizacją, której skutkiem jest zmiana znaczenia semantycznego polskiego rzeczownika korona" (2020).

W przypadku drugiego z członów złożenia koronawirus, tj. rzeczownika wirus, nie odnotowano takich zmian semantycznych. Jak podaje WSJP, słowo wirus ma swoje źródło $w$ języku francuskim virus 'zarazek, coś jadowitego, trującego' oraz w łacinie vĩrus 'jad, sok trujący lub śmierdzący' i występuje obecnie w dwóch znaczeniach: jako wirus grypy, a zatem w znaczeniu medycznym, znanym od ok. 1970 roku, oraz jako wirus komputerowy, czyli $w$ znaczeniu informatycznym. W kontekście tematu artykułu kluczowe jest to pierwsze znaczenie: wirus jako „twór znacznie mniejszy od bakterii, rozmnażający się tylko wewnątrz innego organizmu, powodujący choroby"7. Należy zatem przyjąć, że w przypadku złożenia koronawirus pierwotnym nośnikiem negatywnych skojarzeń jest słowo określane wirus. Jednak wobec rozszerzonego pola semantycznego rzeczownika korona ich źródłem może być także pierwszy człon złożenia. Owo nowe znaczenie sprawia bowiem, że korona- w złożeniu koronawirus może być odczytywana zarówno poprzez nawiązanie do budowy wirusa, czyli jako rodzaj poświaty, korony wokół niego, jak też może nabierać wymiaru temporalnego, gdy pod pojęciem korona kryje się epidemia, czyli czas panowania wirusa i wywoływanej przed niego choroby, czas korony.

Czas korony to czas epidemii, który przyniósł z sobą nowa rzeczywistość, jak zwykło się określać moment, w którym społeczeństwo musiało najpierw dostosować się do różnych obostrzeń i nauczyć się z nimi żyć, a następnie przy okazji ich stopniowego znoszenia powoli powracać do form aktywności sprzed tzw. lockdownu. Pojawienie się nowego koronawirusa zmieniło nie tylko świat medycyny. Wirus ten zaznaczył swoją obecność także $w$ innych obszarach ludzkiej aktywności, $w$ tym $z$ pewnością zaistniał $w$ obszarze komunikacji. Nowa normalność była bowiem budowana i oswajana między innymi dzięki nazywaniu, opisywaniu, ale też wizualizowaniu wielu nowych zjawisk, zachowań, procesów i problemów, które przyniosła z sobą pandemia. Koronawirus stał się motywem obecnym zarówno $w$ sferze języka, jak i w sferze obrazu. Przyjmując różne formy semiotyczne (słowo/obraz), posłużył do wizualizowania informacji w szeroko rozumianej przestrzeni komunikacyjnej, w której - jak podkreśla Maryla Hopfinger - słowo i obraz są „dobrze współobecne, mogą pełnić zarówno samodzielne, jak i komplementarne funkcje; obraz nie tyle wypiera słowo, ile pełnić dzisiaj może zarówno swoiste funkcje przedstawiające, jak i funkcje, które kiedyś przypisywano tylko słowu" (2013: 13, por. także Hopfinger, 2003). Stąd też zaprezentowana tu próba przeanalizowania zjawisk językowych i obrazowych towarzyszących owej nowej normalności na przykładzie tekstów związanych z koronawirusem i wywołaną przez niego pandemią. Wstępem do tej analizy, ale jednocześnie przykładem takiego zróżnicowanego semiotycznie tekstu medialnego może być okładka tygodnika „Polityka” (2020, nr 38) z dnia 16 września 2020 roku, na której na poziomie zarówno języka (koronasceptycy), jak i obrazu (postaci w maseczkach na oczach, brak społecznego dystansu, symbole buntu wobec koronawirusa) nawiązano do rzeczywistości pandemicznej (rys. 1).

${ }^{7}$ [online: https://www.wsjp.pl/inder.php?id_hasla=33927\&id_znaczenia=4213260\&l=27\&ind=0; data dostępu: 1.10.2020]. 


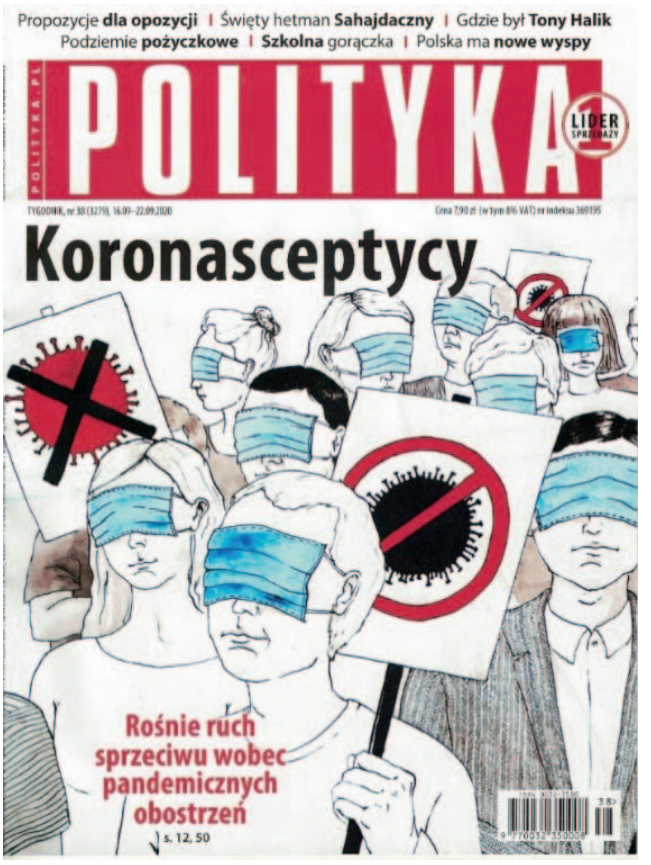

Rys. 1. Okładka tygodnika „Polityka” (2020, nr 38)

W zaprezentowanych poniżej rozważaniach za punkt wyjścia przyjęto subpłaszczyznę językową tekstów medialnych, by następnie w nawiązaniu do niej $w$ dalszej części artykułu przedstawić rozwiązania stosowane na subpłaszczyźnie obrazowej oraz właściwą dla analiz mediolingwistycznych relację język - obraz ${ }^{8}$.

\section{Perspektywa językowa tekstów medialnych poświęconych pandemii koronawirusa}

Koronasceptycy, o których mowa na zaprezentowanej okładce „Polityki” (rys. 1), to tylko jeden z licznych przykładów neologizmów, czyli nowo utworzonych wyrazów i wyrażeń, które powstały $w$ języku polskim wskutek pojawienia się koronawirusa i których zadaniem było nazwanie nowych zjawisk wywołanych pandemią. Wśród tych „pandemicznych" neologizmów można wyróżnić zarówno takie słowa, które już istniały w języku, ale od określonego momentu zaczęto im przypisywać nowe znaczenie (jak np. wspomniana wcześniej korona $w$ znaczeniu epidemii) i $w$ związku z tym uzyskały status neologizmów znaczeniowych, jak i takie, które utworzono $w$ celu nazwania zupełnie nowych przedmio-

${ }^{8}$ Bez wątpienia wartym odnotowania przykładem wielopłaszczyznowej, multimodalnej analizy funkcji okładek 9 polskich tygodników społeczno-politycznych są badania zaprezentowane w artykule Pauliny OlechowsKiej (2018). Badaniu poddano 40 okładek, które nawiązują do tematu metadziennikarstwa i analizowanych pod względem wizualnych kodów semiotycznych oraz semantycznych kodów językowych. 
tów, zjawisk i procesów, i które w związku z tym mają status neologizmów leksykalnych. Wśród reprezentantów tej drugiej grupy można wymienić chociażby takie rzeczowniki, jak koronajęzyk powstały na potrzeby opisania zmian, jakie $w$ czasie epidemii zaszły $w$ języku polskim, czy koronakryzys opisujący „ogół poważnych problemów ekonomicznych, które wystąpiły na skutek pandemii COVID-19, wywołanej przez jedną z odmian koronawirusa"9.

Zdaniem Cierpich-Kozieł, która na podstawie materiału zebranego od 5 marca do 1 maja 2020 wyekscerpowała nowo powstałe złożenia z członem korona-, można wskazać co najmniej 11 typów grup neologizmów, odnoszących się do takich kategorii, jak:

1. rzeczywistość społeczna: coronaściema, koronabzdura, koronachaos, koronamit, koronamitologia, koronaśmieci, koronaproblem;

2. czas izolacji społecznej: koronaczas(y), koronaferie, koronamajówka, koronawakacje;

3. spotkania towarzyskie: koronagrill, koronaparty, koronaparty weekend, koronaspotkanie, koronaurlop;

4. człowiek lub grupa osób: koronacelebryta, koronamenel, koronaoszust, koronasceptyczka, koronateam, koronahiena;

5. system oświaty: koronalekcja, koronamatura;

6. polityka: koronademokracja, koronadyktatura, koronaustawa, koronapolityka, koronawybory;

7. gospodarka: koronacena, koronakryzys, koronaobligacje, koronarecesja;

8. usługi: koronaalert, koronabot, koronainfo, koronamarketing, koronanewsletter, koronaraport;

9. religia: koronamsza, koronakomunia;

10. emocje: koronadepresja, koronanuda, koronahejt, koronapanika, koronaszaleństwo, koronaświrus (jako stan psychiczny);

11. twórczość: koronabajka, koronasłownik, koronasong.

Cierpich-Koziet, 2020

Analizując kategorie zaproponowane przez autorkę, warto podkreślić, że wśród zaprezentowanych tu przykładów można wyróżnić słowa o różnej „trwałości”. Takie neologizmy jak koronamatura, koronaparty, koronakomunia czy koronawybory mają w tym sensie charakter okolicznościowy, że powstały na przykład w związku z trwającymi maturami, majówką czy wyborami. Ich przeciwieństwem są takie rzeczowniki, jak koronaczas(y) czy koronakryzys, które można odnieść do całego okresu pandemii bez łączenia ich z jakimkolwiek konkretnym jej momentem i które $w$ związku z tym mają dużo większe szanse na utrwalenie się $w$ języku. Zdaniem ŁAzıŃSKIEGo (2020), badającego wpływ pandemii koronawirusa na język, większość nowo tworzonych w czasie pandemii słów nie przetrwa próby czasu właśnie dlatego, że są to zuykle pojęcia powiązane w konkretnymi sytuacjami ${ }^{10}$. Tak jak koronakryzys będzie zapewne dłużej wspominany ze względu na swoje długofalowe

${ }^{9}$ [online: https://www.wsjp.pl/inder.php?id_hasla=99539\&ind=0\&w_szukaj=koronakryzys; data dostępu: 1.10.2020].

${ }^{10}$ [online: https://cwid.uw.edu.pl/wplyw-pandemii-koronawirusa-na-jezyk/?fbclid=IwAR3-z_DFOBVVS78OHwbOW8YSSBCYgPQ-7er1Cmrup0MPuWCwDPiOu7XuTZU; data dostępu: 1.10.2020]. 
skutki i ogólnoświatowy zasięg, tak w zbiorowej pamięci koronamajówka nie odegra tak istotnej roli. Jest jeszcze inny podział, który warto zastosować wobec zaprezentowanych przez Cierpich-Kozieł kategorii. Wśród przywołanych przez autorkę neologizmów można bowiem wyróżnić takie, które nazywają elementy świata zmienionego wskutek pandemii (np. koronacena, koronanuda, koronamsza, koronalekcja), oraz takie, które ukazują stosunek nadawcy komunikatu wobec zjawiska pandemii i $w$ tym sensie mają charakter wartościujący (np. coronaściema, koronaświrus). Zjawisko społecznego buntu przeciw koronie („Polityka” 2002, nr 38: 12) zaczęło przybierać na sile w maju 2020 roku, gdy autorka zakończyła już budowanie korpusu badawczego. Stąd wynikać może niewyodrębnienie tej kategorii i umieszczenie $w$ podtypie rzeczywistość społeczna zarówno coronaściemy, koronabzdury, koronachaosu, koronamitu czy koronamitologii, jak i koronaśmieci czy koronaproble$m u$, które wprawdzie służą opisaniu rzeczywistości społecznej, ale dotyczą innych kwestii niż przykłady wskazane $w$ tym podtypie jako pierwsze. Podobnie $w$ przypadku podtypu człowiek lub grupa osób obok koronasceptyczki znalazł się koronacelebryta. W związku z tym, że w ostatnich miesiącach zjawisko buntu wobec pandemii wyraźnie przybrało na sile i znalazło wielu zwolenników, warto wyodrębnić ten właśnie podtyp, by jednocześnie podkreślić, że neologizmy powstałe $w$ czasie pandemii służyć mogą zarówno opisaniu tego, co ona z sobą przyniosła, jak i określeniu stosunku wobec niej, w tym szczególnie podważaniu jej istnienia. Wśród złożeń z członem korona- utworzonych na potrzeby tego nowego podtypu można wymienić koronaparanoję („Polityka” 2020, nr 38: 12), koronateistę (= koronawirusowy ateista, Polki.pl $\left.{ }^{11}\right)$, koronaściemę (już w polskim zapisie graficznym $w$ przeciwieństwie do tego przywołanego przez Cierpich-Kozieł; „Newsweek” 2020, nr 39: 9) czy koronapanikę (= jako lęk świadomie wywoływany w ludziach; "Newsweek” 2020, nr 39: 10). Oprócz neologizmów z członem korona-koronasceptycy wprowadzili do języka polskiego także inne wyrazy ukazujące ich stosunek do pandemii koronawirusa. Należą do nich między innymi:

- covidioci - pogardliwie o ludziach wierzących w koronawirusa („Polityka” 2020, nr 38: 12),

- antycovidowiec ${ }^{12}$,

- wirusowątpiący („Polityka” 2020, nr 38: 14),

- pandemiopsychoza ${ }^{13}$,

- plandemia - pandemia zaplanowana przez globalistów („Polityka” 2020, nr 38: 14),

- infodemia - panika i dezinformacja w czasie pandemii („Tygodnik Powszechny” 2020, nr 39: 12).

Interesującym złożeniem jest słowo covidioci. Powstało ona z dwóch elementów: covid + idioci, przy czym granica pomiędzy nimi właściwie się zatarła: -id- jest cząstką przynależną zarówno do słowa covid, jak i do słowa idioci, w efekcie czego pierwsze słowo płynnie przechodzi $w$ drugie. W semantycznej opozycji do covidioty pozostają wi-

${ }^{11}$ [online: https://polki.pl/magazyn/o-tym-sie-mowi,koronaswirus-wypral-mojej-matce-mozg-teoriispiskowych-i-niewierzacych-w-pandemie-w-sieci-nie-brakuje,10434071,artykul.html; 04.05.2020; data dostępu: 1.10.2020].

12 [online: https://twitter.com/Krzyszt64455392/status/1308371627231637504 (@Krzyszt64455392, 22.09.2020); data dostępu: 1.10.2020].

13 [online: https://twitter.com/KONFEDERACJA_/status/1290618854939467776 (@KONFEDERACJA, 4.08.2020); data dostępu: 1.10.2020]. 
rusowątpiący i jeszcze bardziej radykalny antycovidowiec jako ci, którzy nie tylko nie ulegają pandemiopsychozie, ale są wręcz przekonani o ogólnoświatowym spisku, który określają jako plandemię, czyli zaplanowaną i świadomie realizowaną epidemię. To, jak daleko idące skutki może mieć zaprzeczanie pandemii i jak trudno wejść $w$ dialog z koronasceptykami, podsumował cytowany przez „Tygodnik Powszechny” szef WHO, stwierdzając: "Nie walczymy jedynie z epidemią. Walczymy z infodemią" („Tygodnik Powszechny” 2020, nr 39: 15).

\section{Perspektywa obrazowa tekstów medialnych poświęconych pandemii koronawirusa}

Zaprezentowana na rysunku 1 okładka tygodnika „Polityka” stanowi jeden z licznych przykładów tekstów medialnych, w których $w$ ich warstwie wizualnej realizowanej z użyciem środków językowych i obrazowych podjęto temat pandemii koronawirusa. Pod względem gatunkowym komunikaty te są bardzo różnorodne, obejmują zarówno poważne artykuły, jak i prześmiewcze memy. Na potrzeby prezentowanych tu rozważań zdecydowano się poddać analizie mediolingwistycznej okładki znanych polskich tygodników, by znaleźć odpowiedź na pytanie o to, po jakie rozwiązania multimodalne odwołujące się do designu tekstu (por. Bucher, 2007; Mateja, 2010; Leszkowicz, 2012; LuginbüHL, 2015; MaćKıEWicz, 2017; OlechowsKa, 2018) sięgają nadawcy instytucjonalni, by budować narrację wokół tematu koronawirusa, wzmacniać dotyczący go przekaz werbalny oraz przykuwać uwagę odbiorców.

Przyjmując perspektywę mediolingwistyczną, analizowane okładki tygodników można opisać $w$ kategoriach tzw. płaszczyzn wizualnych:

Płaszczyzny wizualne są powierzchniami, na których dzięki przemyślanemu layoutowi teksty i obrazy tworzą wspólne jednostki znaczeniowe. [...] Skupiają one na sobie uwagę, umożliwiają umieszczenie na najmniejszej nawet powierzchni możliwie największej ilości informacji, pozwalają na różnorodne sposoby prezentacji, strukturyzacji, ukierunkowania i recepcji oraz wspomagają szybką orientację. [...] Jesteśmy dzisiaj otoczeni mnogością płaszczyzn wizualnych wszelkiego typu, w których pismo i obraz, połączone dzięki spajającemu działaniu designu, w sposób nierozerwalny współgrają ze sobą formalnie i treściowo.

SCHMITZ, 2015: 59

Ulrich Schmitz uznaje za zasadne rozróżnienie dwóch typów takich płaszczyzn. Przykładem tzw. słabych płaszczyzn wizualnych (schwache Sehflächen, Schmitz, 2016: 31) mogą być komunikaty realizowane wyłącznie z użyciem środków językowych, których układ na płaszczyźnie stanowi jednak jakiś rodzaj informacji wizualnej. Natomiast tzw. mocne płaszczyzny wizualne (starke Sehflächen, Scнmıтz, 2016: 31) cechuje daleko bardziej zaawansowana różnorodność semiotyczna. W ich przypadku dochodzi zatem do sytuacji, w której kod werbalny współzawodniczy z innymi kodami semiotycznymi. Przykładem mocnych płasz- 
czyzn wizualnych są więc bez wątpienia okładki tygodników, w tym ta zaprezentowana na rysunku 1. Uznając ją za płaszczyznę wizualną, należałoby wskazać dwie współtworzące ją subpłaszczyzny, a mianowicie subpłaszczyznę języka i subpłaszczyznę obrazu. Czytanie płaszczyzny wizualnej w sposób najbardziej typowy dla naszego kręgu kulturowego (od góry do dołu, od lewej do prawej) oznaczałoby, że wzrok odbiorcy spotyka najpierw element subpłaszczyzny języka (neologizm: koronasceptycy) pełniący funkcję nagłówka i sygnalizujący temat przewodni wydania, następnie zaś trafia na subpłaszczyznę obrazu (demostranci z maskami na oczach i transparentami z zakazem wstępu koronawirusa), po czym napotyka element kontynuacji subpłaszczyzny języka: Rośnie ruch sprzeciwu wobec pandemicznych obostrzeń. Spójność subpłaszczyzny języka i subpłaszczyzny obrazu osiągana jest nie tylko dzięki fizycznej bliskości tworzących je elementów, ale przede wszystkim poprzez ich związek semantyczny: podczas gdy na subpłaszczyźnie języka nazywa się ludzi, którzy tworzą ruch sprzeciwu wobec pandemicznych obostrzeń, subpłaszczyzna obrazu ich prezentuje, wyposażając $w$ wizualne atrybuty owego protestu, jakimi są naciągnięte na oczy maseczki, brak społecznego dystansu i transparenty z przekreślonym motywem koronawirusa. Tym samym stanowiący obiekt percepcji formalny design tekstu, tj. motyw graficzny tworzony na płaszczyźnie przez reprezentantów różnych systemów semiotycznych, jest elementem współtworzącym recepcję, tj. budowanie znaczeń z użyciem wzajemnie kontekstualizujących się i zróżnicowanych semiotycznie elementów danego komunikatu wizualnego.

Od marca do września 2020 roku „Polityka” bardzo często czyniła motywem przewodnim swoich okładek właśnie kwestie pandemiczne. Spośród 30 numerów tygodnika, które ukazały się $w$ tym czasie, po motyw ten sięgnięto aż 14 razy: 4 razy $w$ marcu, 4 razy $w$ kwietniu, 3 razy $w$ maju, 2 razy $w$ sierpniu i raz we wrześniu' ${ }^{14}$. Pierwszy raz słowa koronawirus użyto na okładce „Polityki” 3 marca 2020 roku, czyli dzień przed zdiagnozowaniem pierwszego polskiego pacjenta chorego na COVID-19. Pytanie: Idzie zaraza? Jak koronawirus dezorganizuje nasze życie połączono z ryciną z XVII wieku przedstawiającą strój lekarza z czasów epidemii „czarnej śmierci”15. 23 marca 2020 roku motyw przewodni brzmiał Zdalne życie. Uczymy się być razem i pracować na dystans. Okładka ta była komentarzem do wprowadzonej $w$ życie 12 marca decyzji o zawieszeniu zajęć stacjonarnych $w$ szkołach i na uczelniach wyższych oraz przejściu $w$ tryb nauki zdalnej. Z kolei 7 kwietnia na okładkę „Polityki” trafiły Osobne święta - tak nazwano Wielkanoc, którą Polacy spędzali, rezygnując z tradycyjnych, dużych rodzinnych spotkań. 8 sierpnia tytuł użyty na okładce brzmiał Wirus kontratakuje. Mnoża się ogniska zakażeń. Czy wróca restrykcje?, przy czym jego pierwszy człon można potraktować jako intertekstualne nawiązanie do tytułu V części Gwiezdnych wojen brzmiącego Imperium kontratakuje, co dodatkowo potęguje wrażenie zagrożenia ze strony wirusa. Analizując okładki „Polityki”, warto podkreślić, że temat koronawirusa praktycznie nie istniał na nich w czerwcu ani w lipcu 2020 roku, gdy

14 Ostatni włączony do korpusu numer „Polityki” pochodzi z dn. 22.09.2020.

15 „Czarna śmierć” to potoczne określenie dżumy dymienicznej, która powodowała wystąpienie na ciele chorego ciemnych plam spowodowanych krwawymi wybroczynami. Ponieważ z czasem tkanka obumierała i czerniała, w chwili śmierci ciało było zwykle czarne. Najwcześniejsze wzmianki o „czarnej śmierci” w Europie pochodzą z 1350 roku, a jej ostatni przypadek zanotowano na Madagaskarze w 2014 roku (por. Evans, 2019: 200). 
pandemia ustąpiła miejsca wyborom prezydenckim. Chociaż politycy w swoich wypowiedziach nawiązywali do koronowirusa, to jednak temat pandemii nie trafiał już na pierwsze strony tygodników i został wyparty przez politykę. W tym kontekście warto wspomnieć jeszcze jedną okładkę „Polityki”, tym razem z 5 maja 2020 roku, na której połączono oba tematy, tzn. pandemię koronawirusa i wybory prezydenckie (rys. 2).

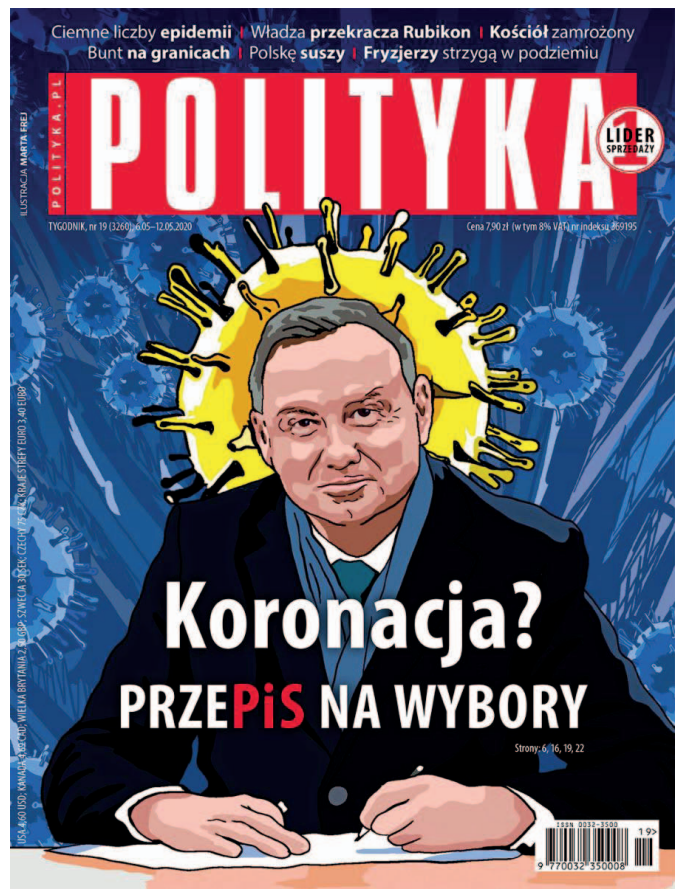

Rys. 2: Okładka tygodnika „Polityka” (2020, nr 19)

Z perspektywy mediolingwistycznej okładka ta jest niezwykle ciekawa, ponieważ na subpłaszczyznach zarówno werbalnej, jak i obrazowej łączy w sobie oba wspomniane tematy, tzn. koronawirusa i politykę. Użyty tu rzeczownik koronacja w swoim pierwotnym znaczeniu oznacza praktykowaną $w$ przeszłości ceremonię uznania kogoś za władcę. Potwierdzeniu, ale też uwspółcześnieniu tego politycznego kontekstu służy podtytuł Przepis na wybory, który dzięki ciekawemu rozwiązaniu z zakresu mikrotypografii (StöckL, 2004; 2015) można interpretować $w$ dwojaki sposób: 1) przepis (= sposób na wybory) lub 2) prze PiS na wybory (przeć do wyborów w sensie za wszelka cenę dążyć do wyborów). O tym, że chodzi tu o szczególne wybory, tzn. wybory w czasie pandemii, świadczy fakt, że autorka tej okładki, Marta Frej, włączyła do subpłaszczyny obrazu motyw koronawirusa. Pojawia się on na drugim planie i dokładnie na wysokości głowy Andrzeja Dudy, przez co przypomina poświatę/koronę wokół głowy ubiegającego się o reelekcję prezydenta. Chociaż zazwyczaj symbol koronawirusa ma kolor niebieski, w tym wypadku autorka zastosowała kolor żółty/złoty, by $w$ ten sposób jeszcze dobitniej podkreślić, jaką ten motyw ma do spełnienia funkcję: to nie wirus, który atakuje, tylko przypominająca go poświata, korona. Łącząc subpłaszczyznę języka i subpłaszczyznę obrazu, należy zatem odczytać rzeczownik 
koronacja jako synonim wyborów prezydenckich odbywających się $w$ czasie panowania koronawirusa. W tym miejscu warto zwrócić uwagę na jeszcze jeden interesujący element, a mianowicie na nawiązanie interobrazowe do słynnego zdjęcia Andrzeja Dudy, jakie zrobiono mu na dworcu $w$ Końskich $w$ marcu 2020 roku, kiedy to prezydent przy stoliku ustawionym na peronie podpisywał nowelizację ustawy w sprawie programu Kolej Plus, zakładającego przywrócenie połączeń kolejowych tam, gdzie zostały one zlikwidowane. Zdjęcie to okazało się bardzo memogenne i - jak dowodzi ta okładka - stało się inspiracją, po którą sięgnął także jeden z opiniotwórczych tygodników. Okładka ta jest bez wątpienia ciekawym przykładem zastosowania designu tekstu (por. BuCHER, 2007; Leszkowicz, 2012), dzięki któremu wzmocniony zostaje semantyczno-funkcjonalny aspekt relacji językowo-obrazowych. Tak budowany przekaz może być odczytywany w różny, niebanalny i atrakcyjny dla odbiorcy sposób.

Motywy związane z pandemią koronawirusa pojawiały się także na okładkach „Newsweeka” i „Tygodnika Powszechnego”, przy czym ich częstotliwość była dużo mniejsza niż w przypadku „Polityki”. W „Tygodniku Powszechnym” temat ten podjęto zaledwie w 2 na 28 wydań, w przypadku „Newsweeka” zaś - w 5 na 28 wydań. Warto jednak podkreślić, że redakcje obu tygodników w swoich 39 numerach sięgnęły po temat pandemii, a dokładniej mówiąc mitów, jakie wokół niej krążą w gronie wspominanych już wcześniej koronasceptyków (rys. 3).

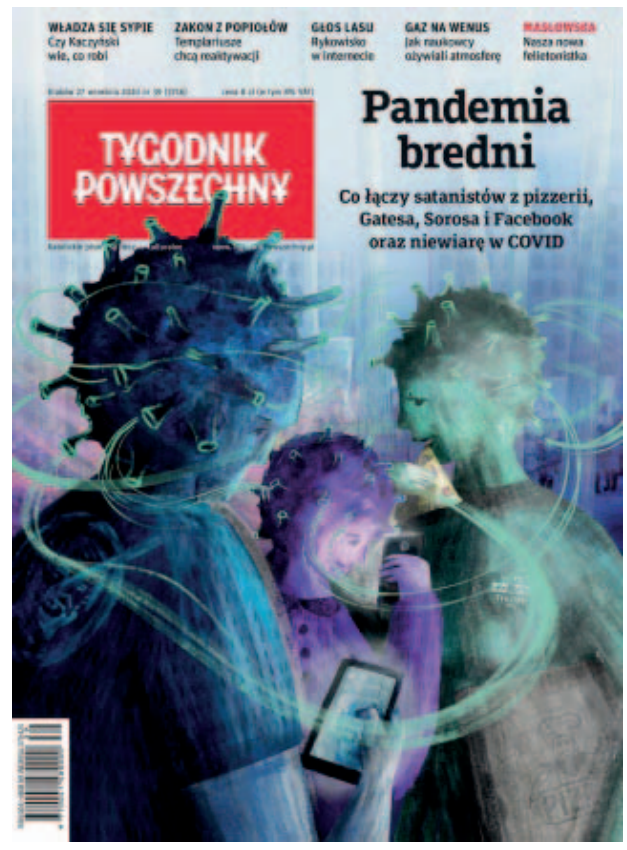

Rys. 3. Okładka „Tygodnika Powszechnego” 2020, nr 39

"Newsweek” przedstawia „kulisy buntu przeciwko pandemii”, podkreślając, że Polak $w$ Covid nie wierzy, i wizualizując ten przekaz za pomocą wizerunku wielkiego wirusa przypominającego ognistą kulę, która próbuje atakować kobietę (czerwień jako kolor czegoś 
groźnego, niebezpiecznego), jednak ta zdejmuje maseczkę i pokazuje wirusowi język („Newsweek" 2020, nr 39: https://www.newsweek.pl/polska/nowy-numer-newsweek-392020-spis-tresci/2bj25ql ${ }^{16}$. Gest, który w stronę atakującego wirusa wykonuje kobieta, tj. wysunięty język widoczny dzięki ściągniętej na znak protestu maseczce, to utrwalony kulturowo motyw niezgody na określoną sytuację, negatywnie ją wartościujący i odznaczający się dużym potencjałem perswazyjnym. W tekście zatytułowanym Koronaściema (s. 9) przytaczane są przykłady reakcji ludzi, którzy reprezentują taki pogląd, tzw. są przekonani, że „nie ma żadnego Covid-a” (s. 9), że „wirus to ściema” (s. 10) i że trzeba „zatrzymać plandemię” (s. 12), bo „tylko dureń wierzy w koronawirusa” (s. 11) i ulega „koronapanice” (s. 10), zamiast tworzyć miejsca, które są „COVID free” (s. 9). Z kolei „Tygodnik Powszechny” opisuje Pandemię bredni, pytając, „Co łączy satanistów z pizzerii, Gatesa, Sorosa i Facebook oraz niewiarę w COVID" (rys. 4). Jako motyw graficzny tej okładki wykorzystano postaci, które dużo bardziej niż ludzi przypominają kosmitów z koronowirusowymi wypustkami na głowach, które to wypustki pozwalają na komunikowanie się i zapewne przekazywanie owych bredni na temat pandemii. W tekście wewnątrz numeru mowa o „śmiercionośnej dezinformacji, która się rozpędza” (s. 12) i o COVID-19, który „dodał wiatru w żagle ruchom antyszczepionkowym" (s. 13). Autorzy tekstu - Agata Kaźmierska i Wojciech Brzeziński - cytują szefa unijnej dyplomacji, Josepa Borella, który podczas konferencji w Monachium alarmował, że „dezinformacja to igranie z życiem ludzi. Dezinformacja może zabijać” (s. 15), po czym porównują infodemię do COVID-19, twierdząc, że „jest do niego w gruncie rzeczy podobna: też roznosi się drogą wirusową, nie ma na nią do tej pory szczepionki, ale tak samo jak rozprzestrzenianiu koronawirusa można jej zapobiegać, zachowując higienę i zdrowy rozsądek” (s. 15). Posłużenie się metaforą wroga („dezinformacja może zabijać”) bez wątpienia służy wzmocnieniu perswazyjności przekazu.

\section{Wnioski}

Pojawienie się koronawirusa bez wątpienia wpłynęło na wiele sfer życia ludzi $w$ różnych krajach świata, zmieniając rzeczywistość, w której dotąd żyli, pracowali, spędzali czas wolny, ale też komunikowali się. Pandemia, zagrożenia z nią związane i generowane przez nią problemy były wiodącymi tematami w mediach analogowych i cyfrowych. Dziennikarze informowali, komentowali i edukowali, ale też diagnozowali obecną sytuację i prognozowali przyszłość. W powstałych $w$ tym czasie tekstach medialnych dało się zauważyć występowanie wielu neologizmów, które z racji czasu powstania i ściśle określonego pola semantycznego można określić mianem neologizmów pandemicznych. Ich cechą wspólną z pewnością jest fakt, że wszystkie odnoszą się do pandemii koronawirusa. Można jednak wyróżnić wśród nich dwie zasadnicze grupy, tj. neologizmy opisujące wszystko to, co nowe

16 Jak podkreśla Olechowska (2018: 127), „kolorystyka okładek czasopism odgrywa istotną rolę nie tylko w decyzji o zakupie produktu, ale także służy konstruowaniu przekazu, który ma na celu wzmacnianie stereotypów lub budowanie danych wizerunków, itp." Autorka dokonuje podziału badanych okładek zależnie od pełnionych przez nie funkcji i wyróżnia okładki z funkcją symboliczną, tj. nawiązujące do kulturowego rozumienia koloru, oraz okładki z funkcją tła, które pod względem stosowanych na nich kolorów uznać należy za neutralne i niebudzące konkretnych skojarzeń. 
i powstałe w związku z pandemią, oraz neologizmy wskazujące na stosunek do pandemii, w tym głównie ją negujące. Analiza korpusu pozwoliła stwierdzić, że słów tych zaczęło istotnie przybywać wraz ze znoszeniem pierwszych obostrzeń (maj 2020 roku), gdy ludzie poczuli, że mogą powoli wracać do swojego dawnego życia i nie muszą już czuć się zagrożeni. Pokazuje to dobitnie, że tzw. koronajęzyk ma też swoją wewnętrzną dynamikę. Wytworzył on pojęcia o różnym stopniu trwałości: są wśród nich takie, które mają charakter okazjonalny i powstały, by nazwać jakiś określony moment, zdarzenie, fakt, ale są też takie, które mają szansę pozostać w języku na dłużej, bo opisują zjawiska i procesy o długofalowym charakterze i wręcz ogólnoświatowym zasięgu. Jak dowodzi analiza mediolingwistyczna okładek polskich tygodników, koronawirus nie tylko generował zmiany $w$ obrębie polskiego leksykonu, ale także posłużył jako motyw graficzny wykorzystany $w$ wielu, zróżnicowanych gatunkowo, tekstach medialnych. Połączenie pojęć z zakresu tzw. koronajęzyka i obrazów, w których wykorzystano motywy kojarzone z pandemią, spowodowało powstanie ciekawych tekstów medialnych, zwykle o dużym potencjale perswazyjnym, które mogą być uznane za atrakcyjne dla odbiorcy, mają szansę przyciągnąć i skupić jego uwagę, zachęcić do refleksji. Niebagatelną rolę odgrywa w tym przypadku design tekstu, dzięki któremu dzielące wspólną płaszczyznę i wzajemnie się kontekstualizujące elementy językowe i obrazowe mogą tworzyć spójne jednostki znaczeniowe, które są źródłem komplementarnego przekazu.

\section{Źródła}

https://cwid.uw.edu.pl/wplyw-pandemii-koronawirusa-na-jezyk/?fbclid=lwAR3-z_DFOBVVS78OHwbOW8YSSBCYgPQ-7er1Cmrup0MPuWCwDPi0u7XuTZU (data dostępu: 1.10.2020).

https://polki.pl/magazyn/o-tym-sie-mowi,koronaswirus-wypral-mojej-matce-mozg-teorii-spiskowych-i-niewierzacych-w-pandemie-w-sieci-nie-brakuje,10434071,artykul.html (4.05.2020; data dostępu: 1.10.2020)

https://sjp.pwn.pl/poradnia/haslo/Koronawirus;20058.html (data dostępu: 1.10.2020).

https://twitter.com/KONFEDERACJA/status/1290618854939467776 (@KONFEDERACJA, 4.08.2020; data dostępu: 1.10.2020).

https://twitter.com/Krzyszt64455392/status/1308371627231637504 (@Krzyszt64455392, 22.09.2020; data dostępu: 1.10.2020).

\section{Słowniki}

WSJP - P. ŻMıgrodzkı, red. [online: https://wsjp.pl/; data dostępu: 10.09.2020].

\section{Literatura}

Bucher H.-J., 2007: Tertdesign und Multimodalität. Zur Semantik und Pragmatik medialer Gestaltungsformen. In: Roth K.S., SpItzmüLler J., Hrsg.: Testdesign und Textwirkung in der massenmedialen Kommunikation. UVK Verlagsgesellschaft mbH. Konstanz, s. 49-76. 
BUCHER H.-J., 2015: Rozumienie multimodalne lub recepcja jako interakcja. Teoretyczne $i$ empiryczne podstawy systematycznej analizy multimodalności. LısıeckA-Czop M., tłum. W: OpıŁowski R., Jarosz J., Staniewski P., red.: Lingwistyka mediów. Antologia tłumaczeń. Atut. Wrocław - Neisse Verlag. Dresden, s. 79-110.

Cierpich-Koziet A., 2020: Koronarzeczywistość - o nowych złożeniach z członem korona - w dobie pandemii. [online: https://jezyk-polski.pl/pl/najpierw-w-sieci/; data dostępu: 10.09.2020].

Evans C., 2019: Historia kolorów. Tajemniczy świat barw. JeżEwsKı W., tłum. Wydawnictwo Bellona. Warszawa. Hopfinger M., 2003: Doświadczenie audiowizualne. Sic! Warszawa.

Hopfinger M., 2013: Czy obraz wypiera słowo. W: Wolny-ZMorzyński K., Furman W., Snopek J., Groń K., red.: Komunikacja wizualna $w$ prasie i $w$ mediach elektronicznych. Wydawnictwo Poltert. Warszawa, s. 11-14.

Klosa-Kückelhaus A., 2020: Neue Wörter in der Coronakrise - von Social Distancing und Gabenzaum. [online: https://ids-pub.bsz-bw.de/frontdoor/deliver/inder/docld/9934/file/KlosaKueckelhaus_Neue_ Woerter_in_der_Coronakrise_2020.pdf; data dostępu: 23.01.2021].

Leszkowicz M., 2012: Projektowanie graficzne a proces czytania i tworzenia wizualnych znaczeń. [online: https://repozytorium.amu.edu.pl/bitstream/10593/5977/1/Infographics-M-E-K-2012.pdf; data dostępu: 10.09.2020].

LugınBühl M., 2015: Design tekstu w wiadomościach telewizyjnych. Multimodalne tworzenie znaczenia poprzez język, obraz i dźwięk. Mac A., tłum. W: OpıŁowskı R., Jarosz J., Staniewski P., red.: Lingwistyka mediów. Antologia tłumaczeń. Atut. Wrocław - Neisse Verlag. Dresden, s. 163-181.

ŁAzı́́sKı M., 2020: Korona (nie tylko wirusa). [online: http://www.slowanaczasie.uw.edu.pl/koronanie-tylko-wirusa/; data dostępu: 10.09.2020].

MAĆKIEWICZ J., 2017: Badanie mediów multimodalnych - multimodalne badanie mediów. [online: https://studiamedioznawcze.pl/Numery/2017_2_69/mackiewicz.pdf; data dostępu: 15.01.2021].

Mateja M., 2010: Czarne, żółte, czerwone. Korelacja grafiki i tematyki w prasie bulwarowej. W: MoCARSKA-Tycowa Z., BielskA-Krawczyк J., red.: Kolor $w$ kulturze. Wydawnictwo Naukowe Uniwersytetu Mikołaja Kopernika. Toruń, s. 211-222.

Müller-Spitzer C., Wolfer S., Koplenig A., Michaelis F., 2020: cOWiDplus Viewer: Sprachliche Spuren der Corona-Krise in deutschen Online-Nachrichtenmeldungen. [online: https://ids-pub. bsz-bw.de/frontdoor/deliver/inden/docId/10042/file/MuellerSpitzer_Wolfer_Koplenig_Michaelis_ cOWIDplus_Viewer_2020.pdf; data dostępu: 23.01.2021].

OlechowsKa P., 2018: Metadziennikarstwo - funkcje okładek społeczno-politycznych w 2016 roku $w$ analizie multimodalnej. W: HoFMAN I., KEPA-FIguRA D., red.: Współczesne media. Media multimodalne. T. 1: Zagadnienia ogólne i teoretyczne. Multimodalność mediów drukowanych. Wydawnictwo Uniwersytetu Marii Curie-Skłodowskiej. Lublin, s. 119-149.

Sснмітz U., 2015: Badanie płaszczyzn wizualnych. Wprowadzenie. Mакоwsка M., tłum. W: OpıŁowSki R., Jarosz J., Staniewski P., red.: Lingwistyka mediów. Antologia tłumaczeń. Atut. Wrocław - Neisse Verlag. Dresden, s. 57-77.

Scнмiтz U., 2016: Randgrammatik und Design. „IDS Sprachreport”, zeszyt 3, s. 8-17.

Sтӧскц H., 2004: Typographie: Gewand und Körper des Textes - Linguistische Überlegungen zu typographischer Gestaltung. „Zeitschrift für Angewandte Linguistik”, Nr. 41, s. 5-48.

Sтӧскц Н., 2015: Czytanie tekstów językowo-obrazowych? Elementy kompetencji podstawowej. Pociask J., tłum. W: OpıŁowski R., Jarosz J., Staniewski P., red.: Lingwistyka mediów. Antologia tłumaczeń. Atut. Wrocław - Neisse Verlag. Dresden, s. 114-137.

Tittula L., Gautier L., Тавовек J., 2020: Zur Sprache der Coronakrise in Finnland, Frankreich und Polen. [online: https://ids-pub.bsz-bw.de/frontdoor/deliver/inden/docld/10222/file/Tiittula_Gautier_ Taborek_Zur_Sprache_der_Coronakrise_in_FIN_FR_und_PL_2020.pdf; data dostępu: 23.01.2021]. 